\title{
Host Plant Effects on the Development, Survival, and Reproduction of Dysmicoccus brevipes (Hemiptera: Pseudococcidae) on Grapevines
}

\author{
Author(s): A. Bertin , L. C. Bortoli , M. Botton, and J.R.P. Parra
}

Source: Annals of the Entomological Society of America, 106(5):604-609. 2013.

Published By: Entomological Society of America

URL: http://www.bioone.org/doi/full/10.1603/AN13030

BioOne (www.bioone.org) is a nonprofit, online aggregation of core research in the biological, ecological, and environmental sciences. BioOne provides a sustainable online platform for over 170 journals and books published by nonprofit societies, associations, museums, institutions, and presses.

Your use of this PDF, the BioOne Web site, and all posted and associated content indicates your acceptance of BioOne's Terms of Use, available at www.bioone.org/page/terms of use.

Usage of BioOne content is strictly limited to personal, educational, and non-commercial use. Commercial inquiries or rights and permissions requests should be directed to the individual publisher as copyright holder. 


\title{
Host Plant Effects on the Development, Survival, and Reproduction of Dysmicoccus brevipes (Hemiptera: Pseudococcidae) on Grapevines
}

\author{
A. BERTIN, ${ }^{1,2}$ L. C. BORTOLI, ${ }^{3}$ M. BOTTON, ${ }^{3}$ and J.R.P. PARRA ${ }^{1}$
}

\begin{abstract}
Ann. Entomol. Soc. Am. 106(5): 604-609 (2013); DOI: http:// dx.doi.org/10.1603/AN13030
ABSTRACT Dysmicoccus brevipes (Cockerell, 1893) (Hemiptera: Pseudococcidae) is one of the most frequent and abundant mealybugs in Brazilian vineyards, where it causes direct and indirect damage to the vines. In this study, we investigated the effect of plant structures, cultivars, and vine rootstocks on the development, survival, and reproduction of $D$. brevipes under laboratory conditions. Leaves of the tablegrape cultivar 'Itália' (Vitis vinifera) and 'Niágara Rosada' (Vitis labrusca) and the vine roots of the rootstocks Paulsen 1103 (Vitis berlandieri $\times$ V. rupestris) and IAC 572 (Vitis caribaea $\times 101-14$ Mgt) were used as host plants. $D$. brevipes developed on different vegetative structures, cultivars, and vine rootstocks. $D$. brevipes showed the shortest developmental period and highest survival and fecundity rates on leaves of cultivar Itália. Survival on leaves was significantly higher than on roots. Roots of IAC 572 were unsuitable for $D$. brevipes development, resulting in nonreproductive females. The mealybugs' longevity on leaves and vine roots was similar. Higher intrinsic and finite rates of increase and net reproductive rate were observed when mealybugs developed on Itália leaves. We concluded that the host plant affects the development and survival of $D$. brevipes and that the choice of the most appropriate cultivar or vine rootstock can help to reduce pest infestation, and is therefore an additional component to be included in the integrated pest management of grapes.
\end{abstract}

KEY WORDS mealybug, life cycle, cultivar, rootstock, grape

Mealybugs (Hemiptera: Pseudococcidae) have become increasingly important pests in many crops (Ben-Dov 1994). In vineyards, they are of concern mainly because of direct infestation of table-grape clusters and indirect damage through virus transmission (Walton and Pringle 2004; Daane et al. 2008, 2012). Mealybugs can feed on all parts of the vine, including the trunk, leaves, and grape clusters, and occasionally on roots (Godfrey et al. 2002, Daane et al. 2008). Direct loss to production occurs when mealybugs infest fruits and excrete honeydew that covers the bunches and leaves, resulting in sooty-mold growth (Flaherty et al. 1992; Godfrey et al. 2002; Daane et al. 2008, 2012). In wine grapes, the presence of mealybugs does not cause economic damage, although some evidence indicates that they can modify the wine quality (Bordeu et al. 2012). However, in table grapes, the presence of mealybugs and the contamination resulting from their feeding can cause cosmetic damage to clusters, reducing marketability (Godfrey et al. 2002, González and Volosky 2004, Daane et al. 2012). Many mealybug species can transmit several important grapevine viruses (Cabaleiro and Segura 1997, Golino et al. 2002, Douglas and Krüger 2008, Bertin et al. 2010), such as the leafroll viruses, which can reduce productivity and grape quality (Komar et al. 2007).

\footnotetext{
${ }^{1}$ Department of Entomology and Acarology, University of São Paulo, 11 Pádua Dias Ave., Piracicaba, SP, Brazil 13418-900.

2 Corresponding author, e-mail: aline.bertin@usp.br.

${ }^{3}$ Laboratory of Entomology, Embrapa Grape and Wine, 515 Livramento St., Bento Gonçalves, RS, Brazil 95700-000.
}

The several species of mealybugs associated with grapevines in Brazil include Planococcus citri (Risso, 1813), Planococcus minor (Maskell, 1897), Pseudococcus maritimus (Ehrhorn, 1900), Pseudococcus longispinus (Targioni-Tozetti, 1867), Pseudococcus viburni (Signoret, 1875), and Dysmicoccus brevipes (Cockerell, 1893) (Daane et al. 2012).

The identification of $D$. brevipes occurrence on grapes is relatively new (Morandi Filho, 2008). This mealybug is primarily a pest of pineapple in Brazil (Silva et al. 1968). On grapes, the species has been mainly found on roots, but it can also infest leaves and bunches, causing significant damage during harvest (Daane et al. 2012). No information is available about the life cycle of $D$. brevipes on grapes. Given its occurrence on roots, this species may be important when replanting vineyards, which may lead to reinfestation and contamination (if this species is also a virus vector), as for Pseudococcus calceolariae (Maskell, 1879) in New Zealand (Bell et al. 2009). In this study, we investigated the development, survival, and reproduction of $D$. brevipes on leaves of two table-grape cultivars and roots of two vine rootstocks.

\section{Materials and Methods}

Maintenance of Insect Colony and Host Plants. A colony of $D$. brevipes was initiated in May 2008 with adult females originally collected from infested fig roots. The colony was maintained for $\sim 15$ generations 
on squash (Cabotiá variety, Cucurbita maxima $\times \mathrm{Cu}$ curbita moschata) in controlled conditions $\left(25 \pm 2^{\circ} \mathrm{C}\right.$, $70 \pm 10 \%$ relative humidity $[\mathrm{RH}]$, and a photoperiod of 14:10 [L:D] h).

The varieties of table grapes that are most commonly grown in Brazil were selected for the study. Leaves of the cultivars 'Itália' (Vitis vinifera) and 'Niágara Rosada' (Vitis labrusca) and the vine rootstocks Paulsen 1103 (Vitis berlandieri $\times$ Vitis rupestris) and IAC 572 (Vitis caribaea $\times 101-14$ Mgt) were used as host. The bioassays were conducted by using leaves of adult plants collected in vineyards free from insecticide application. The vine rootstocks were cultivated in a greenhouse with one plant (1-yr-old) per container (3 liters).

Development and Survivorship. To determine the development time and survival rate of $D$. brevipes, adult females from the laboratory colony were isolated in petri dishes (diameter $6.0 \mathrm{~cm}$ ) with Itália leaf discs (diameter $3.5 \mathrm{~cm}$ ) until oviposition. First-instar nymphs (<24-h-old) were transferred to host-plant leaf discs (diameter $3.5 \mathrm{~cm}$ ) and vine roots (length 4 $\mathrm{cm}$ ) in petri dishes (diameter $6 \mathrm{~cm}$ ) containing a layer $(1 \mathrm{~cm})$ of $3 \%$ agar-water. In total, 150 nymphs were placed individually on leaf discs from each cultivar, and 250 nymphs on each root piece of the vine rootstock. Mealybugs were transferred to new leaves or roots every $5 \mathrm{~d}$ to ensure a supply of fresh food.

The experiments were conducted in the laboratory under controlled conditions at $25 \pm 2{ }^{\circ} \mathrm{C}, 70 \pm 10 \% \mathrm{RH}$, and a photoperiod of 14:10 (L:D) h. The progress of development was checked every $2 \mathrm{~d}$ under a binocular microscope and distinguished based on the occurrence of molting exuviae. The survival rate for each stage is presented as the percentage of individuals that successfully developed to the next stage. The sex of individual mealybugs could not be determined at the egg and first-crawler stages; sex could first be distinguished in the second instar, when males form a cocoon to complete their development (McKenzie 1967).

Reproduction and Longevity. We measured the longevity and reproductive performance of all insects that successfully molted to the adult stage in the development/survivorship study. The longevity of adult females was checked every $2 \mathrm{~d}$, and insects were maintained individually on leaf discs and vine rootstocks of each host plant. The number of progeny produced from unmated females was recorded, and the nymphs laid each day were removed from the leaf or root. The duration from adult emergence to oviposition (prereproductive period) and the number of days that the females reproduced (reproductive period) were determined. The experiments were conducted under the same conditions as previously described.

Life Table and Data Analysis. Life-table parameters for $D$. brevipes on Itália and Niágara Rosada leaves were calculated. These included intrinsic rate of increase $\left(r_{m}\right)$, finite rate of increase $(\lambda)$, net reproductive rate $\left(R_{o}\right)$, mean generation time $\left(T_{G}\right)$, and doubling time (DT). The means and standard errors of the life-table parameters were estimated based on jack-
Table 1. Results of statistical analysis for development time and longevity of Dysmicoccus brevipes reared on leaves and vine roots of grapes

\begin{tabular}{lccc}
\hline \multicolumn{1}{c}{ Traits } & & Test statistic & \\
\cline { 1 - 1 } Leaf or root & & P value \\
\hline First instar (development time) & & $2.85(1)$ & 0.233 \\
Second instar (development time) & & $10.03(1)$ & 0.086 \\
Third instar (development time) & & $43.20(1)$ & 0.022 \\
Nymphal period & & $19.48(1)$ & 0.047 \\
Longevity & $10.41(1)$ & 0.084 \\
\hline
\end{tabular}

knife resampling (Maia et al. 2000) and were compared by using a $t$-test $(\alpha=0.05)$. Life-table parameters for D. brevipes on IAC 572 and Paulsen 1103 roots were not estimated because mealybugs did not produce offspring when reared on IAC 572 roots and there was a low number of reproductive females on Paulsen 1103 roots.

Development time and adult longevity were analyzed by using nested analysis of variance of the combined data set, where leaves and roots were the main fixed factor and the cultivars or rootstocks were the random factor nested within leaves/roots. To test for the significance within groups (leaves or roots), a $t$-test was applied $(\alpha=0.05)$ ( $\mathrm{R}$ Development Core Team 2012).

The reproductive periods were analyzed with analysis of variance, followed by Tukey's test to separate the means at $\alpha=0.05$. The effect of host plants on survival of immature stages and adult fecundity were analyzed fitting a generalized linear model of the binomial and Poisson types, respectively (Nelder and Wedderburn 1972).

\section{Results}

Development and Survivorship. No D. brevipes males were observed from first-instar nymphs maintained on leaves and roots, indicating the occurrence of thelytokous parthenogenesis. The nymphal stage of $D$. brevipes females consisted of three instars on all host plants. The development time of the first or second instar did not differ between leaves and rootstocks (Tables 1 and 2). The greatest differences were observed in the third instar, with all rootstocks providing a shorter development time, on average, half the time, compared with leaves (Tables 1 and 2 ).

The $D$. brevipes nymphal period was significantly influenced by the host plants, with a shorter development time on rootstocks than on leaves (Tables 1 and 2). On leaves, there was a significant difference between cultivars, with the longest nymphal period observed on Niágara Rosada (Table 2); on roots, the development period ranged from 31 to $33 \mathrm{~d}$ and was not influenced by the rootstock variety.

The host tissue had a strong effect on $D$. brevipes survival (Table 3). On Itália and Niágara Rosada leaves, the survival rate of the first instar was $>90 \%$, reaching almost $100 \%$ on Itália. On the vine rootstocks, survival did not exceed $30 \%$. 
Table 2. Mean number of days $( \pm \mathrm{SE})$ for each developmental stage of $\boldsymbol{D}$. brevipes reared on Itália (Vitis vinifera) and Niágara Rosada (Vitis labrusca) table-grape leaves and on Paulsen 1103 (Vitis berlandieri $\times$ Vitis rupestris) and IAC $572($ Vitis caribaea $\times 101-14$ Mgt) roots

\begin{tabular}{|c|c|c|c|c|c|}
\hline \multirow{2}{*}{$\begin{array}{l}\text { Vegetative } \\
\text { structure }\end{array}$} & \multirow{2}{*}{ Cultivar or rootstock } & \multicolumn{3}{|c|}{ Instars } & \multirow{2}{*}{ Nymphal period $(n)^{a}$} \\
\hline & & First $(n)^{a}$ & Second $(n)^{a}$ & Third $(n)^{a}$ & \\
\hline \multirow[t]{4}{*}{ Leaf } & Itália & $13.46 \pm 0.48(144)$ & $12.76 \pm 0.56(135)$ & $17.97 \pm 0.79(85)$ & $42.20 \pm 1.07(82)^{*}$ \\
\hline & Niágara Rosada & $14.13 \pm 0.52(136)$ & $13.72 \pm 0.54(110)$ & $20.46 \pm 1.09(70)$ & $47.23 \pm 1.39(68)^{*}$ \\
\hline & $t(\mathrm{df})$ & $-0.930(274.95)$ & $-1.22(241.99)$ & $-1.864(132.21)$ & $-2.846(133.34)$ \\
\hline & $P$ value & 0.353 & 0.223 & 0.064 & 0.005 \\
\hline \multirow[t]{4}{*}{ Root } & Paulsen 1103 & $14.85 \pm 0.54(74)$ & $11.42 \pm 0.82(40)$ & $8.92 \pm 1.30(13)$ & $33.69 \pm 1.76(13)$ \\
\hline & IAC 572 & $14.25 \pm 0.51(74)$ & $10.25 \pm 0.87(36)$ & $10.40 \pm 0.92(15)$ & $31.43 \pm 1.40(15)$ \\
\hline & $t(\mathrm{df})$ & $-0.793(145.26)$ & $-0.979(72.95)$ & $0.92(22.36)$ & $-0.929(26.25)$ \\
\hline & $P$ value & 0.428 & 0.330 & 0.366 & 0.361 \\
\hline
\end{tabular}

Means $( \pm \mathrm{SE}$ ) followed by asterisks were significantly different at $\alpha=0.05$ according to the Student $t$-test used to perform unpaired comparisons.

${ }^{a}$ Number of individuals observed.

In the second instar, viability differed significantly between Itália and Niágara Rosada leaves, with higher survival for mealybugs reared on Itália leaves. Survival of second instars on roots did not differ between the rootstocks (Table 3 ). The highest survival in the third instar was observed on Itália and Niágara Rosada leaves, whereas the highest mortality was observed on Paulsen 1103 roots (Table 3).

Survival rates from first-instar nymph to adult ranged from $5 \%$ on roots of Paulsen 1103 to $64 \%$ on Itália leaves (Table 3). Despite this low survival on roots, mealybugs that were reared on roots had the shortest developmental period, indicating that the roots as food source for the species allow D. brevipes development.

Longevity and Reproduction. Female life span on all plants was similar (Table 1). Female longevity on Itália and Niágara Rosada leaves (37.21 \pm 1.83 and $42.52 \pm 2.23$, respectively) $(t=-1.83 ; \mathrm{df}=138.06 ; P>$ $0.05)$ as well as on Paulsen 1103 and IAC 572 roots $(27.53 \pm 5.83$ and $18.56 \pm 2.30$, respectively $)(t=$ -1.43 ; df $=15.73 ; P>0.05$ ) was not influenced by the cultivar or rootstock variety.

No significant difference was found in the preoviposition and oviposition periods between leaves of the two cultivars; however, females reared on Itália leaves showed higher fecundity (Table 4). Fecundity on Paulsen 1103 roots was not included in the statistical analysis because of the low number of replicates and high variance (only four females were reproductively active, and the mean number of nymphs per female was $57.50 \pm 35.33)$. IAC 572 rootstock was unsuitable for the development of $D$. brevipes, resulting in nonreproductive females.

Life-Table Parameters. The demographic parameters for $D$. brevipes differed between the cultivars Itália and Niágara Rosada. The net reproductive rate $\left(R_{o}\right)$ that represents the number of times that the population increases per generation showed that the $D$. brevipes population increased 20 times per generation on Itália leaves and $\approx 14$ times on Niágara Rosada (Table 5).

The other life-table parameters were also affected by the host plant. Higher values of the intrinsic rate of increase $\left(r_{m}\right)$ and finite rate of increase $(\lambda)$ were also observed on Itália leaves (Table 5). The mean generation time $\left(\mathrm{T}_{\mathrm{G}}\right)$ was lower for mealybugs reared on Itália leaves (Table 5), mainly because of the shorter developmental period. Following the same trend, the time required for doubling the population (DT) was also shorter on Itália leaves (Table 5).

\section{Discussion}

Different cultivars and vine rootstocks had a pronounced effect on the development, survival, and reproduction of $D$. brevipes. This mealybug species could develop on leaves and roots of grapevines, although the development time differed between hosts. The differences observed in the life cycle may be related to nutritional factors, as different plant species show differences in nutritional quality that can affect insect survival and development.

Table 3. Survival rate (mean $\pm \mathrm{SE}, \%)$ for each developmental stage of $\boldsymbol{D}$. brevipes reared on Itália $(V$. vinifera) and Niágara Rosada $($ V. labrusca) table-grape leaves and on Paulsen $1103($ V. berlandieri $\times$ V. rupestris $)$ and IAC $572($ V. caribaea $\times 101-14$ Mgt $)$ roots

\begin{tabular}{|c|c|c|c|c|c|}
\hline \multirow{2}{*}{$\begin{array}{l}\text { Vegetative } \\
\text { structure }\end{array}$} & \multirow{2}{*}{ Cultivar or rootstock } & \multicolumn{3}{|c|}{ Instars } & \multirow{2}{*}{ Nymphal period $(n)^{a}$} \\
\hline & & First $(n)^{a}$ & Second $(n)^{a}$ & Third $(n)^{a}$ & \\
\hline \multirow[t]{2}{*}{ Leaf } & Itália & $99.31 \pm 0.69 \mathrm{a}(145)$ & $99.26 \pm 0.73 a(136)$ & $65.38 \pm 4.18 \mathrm{ab}(130)$ & $63.56 \pm 4.23 \mathrm{a}(129)$ \\
\hline & Niágara Rosada & $94.44 \pm 1.91 \mathrm{a}(144)$ & $85.93 \pm 3.08 \mathrm{~b}(128)$ & $72.16 \pm 4.57 \mathrm{a}(97)$ & $56.55 \pm 4.48 \mathrm{a}(122)$ \\
\hline \multirow[t]{2}{*}{ Root } & Paulsen 1103 & $30.45 \pm 2.95 b(243)$ & $54.05 \pm 5.83 c(74)$ & $33.33 \pm 7.64 \mathrm{c}(39)$ & $5.37 \pm 1.45 \mathrm{~b}(242)$ \\
\hline & IAC 572 & $30.45 \pm 2.95 b(243)$ & $51.42 \pm 6.01 \mathrm{c}(70)$ & $41.66 \pm 8.33 \mathrm{bc}(36)$ & $6.27 \pm 1.55 \mathrm{~b}(239)$ \\
\hline
\end{tabular}

Means within each column followed by the same letters are not significantly different (generalized linear model with binomial distribution) according to the CIs.

${ }^{a}$ Number of individuals observed. 
Table 4. Duration of preoviposition and oviposition periods (mean \pm SE, days) and mean number of nymphs per female (mean \pm $\mathrm{SE}$ ) of female $D$. brevipes reared on grape leaves and vine roots

\begin{tabular}{|c|c|c|c|c|}
\hline \multirow{2}{*}{ Vegetative structure } & \multirow{2}{*}{ Cultivar or rootstock ${ }^{a}$} & \multicolumn{2}{|c|}{ Days $^{b}(n)^{c}$} & \multirow{2}{*}{ Fecundity $^{d}$} \\
\hline & & Preoviposition period & Oviposition period & \\
\hline \multirow[t]{2}{*}{ Leaf } & Itália & $33.59 \pm 1.46 \mathrm{a}(38)$ & $15.76 \pm 0.97 \mathrm{a}(38)$ & $30.86 \pm 2.74 a(38)$ \\
\hline & Niágara Rosada & $35.25 \pm 1.16 \mathrm{a}(38)$ & $19.23 \pm 1.18 \mathrm{a}(38)$ & $24.23 \pm 2.02 b(38)$ \\
\hline \multirow[t]{3}{*}{ Root } & Paulsen 1103 & $29.00 \pm 2.51 \mathrm{a}(4)$ & $20.25 \pm 3.22 \mathrm{a}(4)$ & $-^{e}$ \\
\hline & $F(\mathrm{df})$ & $1.29(2)$ & $2.91(2)$ & - \\
\hline & $P$ value & 0.282 & 0.060 & 0.000 \\
\hline
\end{tabular}

${ }^{a}$ Females did not oviposit on rootstock IAC 572.

${ }^{b}$ Means within a column followed by the same letters are not significantly different at $\alpha=0.05$ (Tukey test).

${ }^{c}$ Number of individuals observed.

${ }^{d}$ Means within a column followed by the same letters are not significantly different (GLM with Poisson distribution) according to the confidence intervals.

${ }^{e}$ Fecundity on Paulsen 1103 roots was not included in the statistical analysis because of the low number of replicates and high variance (only four females were reproductively active).

The influence of the host plant on life-history traits has also been demonstrated with other mealybug species. The development time of $P$. citri on grape leaves ('Cabernet Sauvignon,' 'Isabel,' and Itália) and vine roots (Isabel, 101-14, IAC 572) was shorter than that observed on Itália berries (Morandi Filho et al. 2008). These authors also observed that $P$. citri did not complete its life cycle on IAC 572 roots and produced infertile adults when reared on Itália berries (Morandi Filho et al. 2008).

The extended nymphal period of $D$. brevipes on Niágara Rosada leaves may be because of lower nutritional quality, as a more appropriate food usually shortens development (Parra 2001), as observed for the development time of the third instar and also for the nymphal period of $D$. brevipes on both rootstocks.

Not all plants or parts of them are nutritionally adequate for sap-sucking insects, as in the case of mealybugs. The nitrogen content of the host plant is crucial for the development of phytophagous insects, and the concentration of soluble nitrogen, in the form of free amino acids, can vary according to the species, variety, and part of the plant (Risebrow and Dixon 1987). The hypothesis for the shorter developmental time and increased occurrence of this species on roots in the field is that the nitrogen concentration is higher

Table 5. Life-table parameters (mean $\pm \mathrm{SE}$ ) of $D$. brevipes reared on Itália ( $V$. vinifera) and Niágara Rosada ( $V$. labrusca) table-grape leaves

\begin{tabular}{lccc}
\hline \hline & \multicolumn{2}{c}{ Host plant } & \\
\cline { 2 - 3 } Parameters & $\begin{array}{c}\text { Itália }(V . \\
\text { vinifera })\end{array}$ & $\begin{array}{c}\text { Niágara } \\
\text { Rosada }(V . \\
\text { labrusca })\end{array}$ & $P$ value \\
\hline $\begin{array}{c}\text { Net reproductive } \\
\text { rate }\left(\mathrm{R}_{\mathrm{o}}\right)\end{array}$ & $19.82 \pm 1.74$ & $13.76 \pm 1.13$ & $P<0.0049$ \\
$\begin{array}{c}\text { Intrinsic rate of } \\
\text { increase }\left(\mathrm{r}_{\mathrm{m}}\right)\end{array}$ & $0.037 \pm 0.00$ & $0.029 \pm 0.00$ & $P<0.0000$ \\
$\begin{array}{c}\text { Mean generation } \\
\text { time }\left(\mathrm{T}_{\mathrm{G}}\right)\end{array}$ & $80.61 \pm 0.54$ & $89.39 \pm 0.58$ & $P<0.0000$ \\
$\begin{array}{c}\text { Population } \\
\text { doubling time } \\
(\mathrm{DT})\end{array}$ & $18.66 \pm 0.62$ & $23.57 \pm 0.74$ & $P<0.0000$ \\
$\begin{array}{c}\text { Finite rate of } \\
\text { increase }(\lambda)\end{array}$ & $1.037 \pm 0.00$ & $1.029 \pm 0.00$ & $P<0.0000$ \\
\hline
\end{tabular}

in roots than in leaves, because the vine has the ability to store nitrogen in the perennial parts of the plant, especially the roots, for subsequent mobilization and redistribution (Brunetto et al. 2005).

Evidence suggests that high levels of chemical fertilizers can cause nutritional imbalances in the plant, increasing its susceptibility to insect pressure (Altieri and Nicholls 2003). Hogendorp et al. (2006) studied the influence of nitrogen concentration on the reproduction and development of the citrus mealybug $P$. citri on coleus (Solenostemon scutellarioides L. Codd). Their results showed that higher nitrogen concentrations, in the form of supplemental fertilizers, led to high reproductive capacity, larger female size, and shorter development times. Nitrogen also affected Macrosiphum euphorbiae (Thomas) (Hemiptera: Aphididae), which when reared on plants without fertilizers or with a low nitrogen level had lower reproductive performance and longevity, thereby demonstrating the importance of this nutrient for insect feeding (Jansson and Ekbom 2002). However, without a quantitative measurement of the nitrogen concentrations in the leaves and vine roots in this study, the effects of nitrogen on the development of $D$. brevipes remain speculative.

The percentage survival differed between host plants. The low survival on roots may be because of antibiosis, when the host plant adversely affects the biology of the phytophagous insect, reducing the size, longevity, and fecundity and increasing mortality; or alternatively may indicate that this mealybug does not prefer to feed on roots (Schoonhoven et al. 2005).

The age of the host plant can also affect the nutrition of phloem sap-sucking insects, owing to physiological changes in plants and in the availability of nutrients (Lazzari and Zonta-de-Carvalho 2009). Another possibility is that the experiments were conducted in the laboratory, which might be a factor in the low survival rate. The exposure of the roots in petri dishes may have affected the development of $D$. brevipes, which in the field remains protected and covered by the soil.

$D$. brevipes proved to be able to develop on Itália and Niágara Rosada leaves and on IAC 572 and Paulsen 1103 roots. Itália leaves were most suitable for the 
species development because of the shorter developmental period combined with higher survival and fecundity, although the development period was shorter when the mealybugs fed on roots, regardless of the rootstock used. This is consistent with field observations that $D$. brevipes is the most common species on vine roots in southern Brazil (M.B., unpublished data).

The development period (from first-instar nymph to adult) of $D$. brevipes on leaves of different pineapple cultivars, its main host plant, was the same as that observed on vine roots in this study (Santa-Cecília et al. 2004). However, the survival of $D$. brevipes on pineapple cultivars (Santa-Cecília et al. 2004) was lower than the survival rate obtained on the tablegrape leaves in this study, suggesting that the host plant strongly influences the species development. Furthermore, in the adult phase, the females' longevity on table-grape leaves was greater than for $D$. brevipes maintained on different pineapple cultivars (Santa-Cecília et al. 2004, Colen et al. 2000).

Regarding reproductive performance, females were not able to reproduce on IAC 572 roots. Some vine rootstocks generally show high vigor and resistance to the main soil pests, including IAC 572, which is resistant to phylloxera, Daktulosphaira vitifoliae (Fitch, 1856) (Hemiptera: Phylloxeridae) (Nachtigal 2003). This resistance may explain the low survival rate and reproductive capacity of $D$. brevipes on this host, as also observed for P. citri (Morandi Filho et al. 2008).

The mean number of nymphs per female on Paulsen 1103 roots was higher than the fecundity on leaves, but this average was based on only four females, and these data were not included in the statistical analysis. Despite the low number of reproductive females, this rootstock allows $D$. brevipes development. On leaves, female fecundity was higher on Itália.

The oviposition period was similar on leaves and vine roots, averaging $32 \mathrm{~d}$. Menezes (1973), studying the $D$. brevipes life cycle on pineapple, noted that only fertilized females were able to produce offspring after a preoviposition period of about $8 \mathrm{~d}$. Comparison with the results of this study suggests that the preoviposition period is shorter in females that reproduce sexually.

Life-table analysis suggested that $D$. brevipes has a greater potential to increase its population level on Itália leaves compared with Niágara Rosada leaves. $D$. brevipes may be better adapted to $V$. vinifera than to V. labrusca. Different Vitis species can show differential susceptibility to pests, as in the famous case of the Grape phylloxera, Da. vitifoliae (Fitch), which have coevolved with American Vitis species, rarely causing damage (Granett et al. 1996). However, other Vitis species like European grape species (V. vinifera) are highly susceptible to the Grape phylloxera damage (Granett et al. 1996).

We conclude that the host plant can affect the development and survival of $D$. brevipes and that the choice of the appropriate cultivar or rootstock can help to reduce pest infestation. This is an additional component to be included in integrated pest management systems. The use of the Niágara Rosada variety and the IAC 572 rootstock would be an effective strategy to reduce $D$. brevipes infestation in the field, whereas the Itália variety and the Paulsen 1103 rootstock tend to favor mealybug infestation.

\section{Acknowledgments}

We thank Janet W. Reid (J.W.R. Associates) for English and technical corrections and the Conselho Nacional de Desenvolvimento Científico e Tecnológico for granting a scholarship to the first author.

\section{References Cited}

Altieri, M. A., and C. I. Nicholls. 2003. Soil fertility management and insect pests: harmonizing soil and plant health in agroecosystems. Soil Till. Res. 72: 203-211.

Bell, V. A., R.G.E. Bonfiglioni, J.T.S. Walker, P. L. Lo, J. F. Mackay, and S. E. McGregor. 2009. Grapevine leafrollassociated virus 3 persistence in Vitis vinifera remnant roots. J. Plant Pathol. 91:527-533.

Ben-Dov, Y. 1994. A systematic catalogue of the mealybugs of the world (Insecta: Homoptera: Coccoidea: Pseudococcidae and Putoidae) with data on geographical distribution, host plants, biology and economic importance. Intercept, Andover, United Kingdom.

Bertin, S., V. Cavalieri, C. Graziano, and D. Bosco. 2010. Survey of mealybugs (Hemiptera: Pseudococcidae) vectors of Ampelovirus and Vitivirus in vineyards of northwestern Italy. Phytoparasitica 38: 401-409.

Bordeu, E., D. O. Troncoso, and T. Zaviezo. 2012. Influence of mealybug (Pseudococcus spp.)-infested bunches on wine quality in Carmenere and Chardonnay grapes. Int. J. Food Sci. Tech. 47: 232-239.

Brunetto, G., J. Kaminski, G.W.B. Melo, L. C. Gatiboni, and S. Urquiaga. 2005. Absorção e redistribuição do nitrogênio aplicado via foliar em videiras jovens. Rev. Bras. Fruticultura 27: 110-114.

Cabaleiro, C., and A. Segura. 1997. Field transmission of grapevine leafroll associated virus $3(\mathrm{GLRaV}-3)$ by the mealybug Planococcus citri. Plant Dis. 81: 283-287.

Colen, K.G.F., L.V.C. Santa-Cecília, J. C. Moraes, and P. B. Reis. 2000. Efeitos de diferentes temperaturas sobre a biologia da cochonilha pulverulenta Dysmicoccus brevipes (Cockerell, 1893) (Hemiptera: Pseudococcidae). Rev. Bras. Fruticultura 22: 248-252.

Daane, K. M., M. L. Cooper, S. V. Triapitsyn, V. M. Walton, G. Y. Yokota, D. R. Haviland, W. J. Bentley, K. E. Godfrey, and L. R. Wunderlich. 2008. Vineyard managers and researchers seek sustainable solutions for mealybugs, a changing pest complex. Calif. Agric. 62: 167-176.

Daane, K. M., R.P.P. Almeida, V. A. Bell, J.T.S. Walker, M. Botton, M. Fallahzadeh, M. Mani, J. L. Miano, R. Sforza, V. M. Walton, et al. 2012. Biology and management of mealybugs in vineyards, pp. 271-307. In N. J. Bostanian, C. Vincent, R. Isaacs. (eds.), Arthropod Management in Vineyards: Pests, Approaches, and Future Directions. Springer, Dordrecht, The Netherlands.

Douglas, N., and K. Krüger. 2008. Transmission efficiency of Grapevine leafroll-associated virus $3(\mathrm{GLRaV}-3)$ by the mealybugs Planococcus ficus and Pseudococcus longispinus (Hemiptera: Pseudococcidae). Eur. J. Plant Pathol. 122: 207-212.

Flaherty, D. L., P. A. Philips, E. F. Legner, W. L. Peacock, and W. J. Bentley. 1992. Mealybugs, pp. 159-165. In D. L. Flaherty, L. P. Christensen, W. T. Lanini, J. J. Marois, P. A. 
Phillips, and L. T. Wilson (eds.), Grape Pest Management. University of California, Oakland, CA.

Godfrey, K. E., K. M. Daane, W. J. Bentley, R. J. Gill, and R. Malakar-Kuenen. 2002. Mealybugs in California vineyards. University of California Agriculture \& Natural Resources (UC DANR) Publ. 21612. Oakland, CA.

Golino, D. A., S. T. Sim, R. Gill, and A. Rowhani. 2002. California mealybugs can spread grapevine leafroll disease. Calif. Agric. 56: 196-201.

González, R. H., and C. Volosky. 2004. Chanchitos blancos y polillas de la fruta: problema cuarentenarios de la fruta de exportación. Rev. Frutícola 25: 41-62.

Granett, J., M. A. Walker, J. De Benedictis, G. Fong, H. Lin, and E. Weber. 1996 California grape phylloxera are more variable than expected. Calif. Agric. 50: 9-13.

Hogendorp, B. K., R. A. Cloyd, and J. M. Swiader. 2006. Effect of nitrogen fertility on reproduction and development of citrus mealybug, Planococcus citri Risso (Homoptera: Pseudococcidae), feeding on two colors of coleus, Solenostemon scutellarioides L. Codd. Environ. Entomol. 35: 201-211.

Jansson, J., and B. Ekbom. 2002. The effect of different plant nutrient regimes on the aphid Macrosiphum euphorbiae growing on petunia. Entomol. Exp. Appl. 104: 109-116.

Komar, V., E. Vigne, G. Demangeat, and M. Fuchs. 2007. Beneficial effect of selective virus elimination on the performance of Vitis vinifera cv. Chardonnay. Am. J. Enol. Viticult. 58: 202-210.

Lazzari, S.M.N., and R. C. Zonta-de-Carvalho. 2009. Sugadores de seiva (Aphidoidea). In A. R. Panizzi and J.R.P. Parra, (eds.), Bioecologia e Nutrição de Insetos: Base Para o Manejo Integrado de Pragas. Embrapa Informação Tecnológica, Brasília, DF.

Maia, A. H., A. J. Luiz, and C. Camapanhola. 2000. Statistical inference on associated fertility life table parameters using Jackknife technique: computational aspects. J. Econ. Entomol. 93: 511-518.

McKenzie, H. L. 1967. Mealybugs of California with taxonomy, biology, and control of North American species (Homoptera: Coccoidea: Pseudococcidae). University of California Press, Berkeley, CA.

Menezes, E. B. 1973. Bioecologia e controle da cochonilha farinhosa do abacaxi Dysmicoccus brevipes (Cockerell, 1893) Ferris, 1950 (Homoptera: Pseudococcidae). M.S. thesis, Escola Superior de Agricultura "Luiz de Queiroz", Universidade de São Paulo, Piracicaba.

Morandi Filho, W. J. 2008. Cochonilhas-farinhentas associadas à videira na Serra Gaúcha, bioecologia e controle de Planococcus citri (Risso, 1813) (Hemiptera: Pseudococcidae). Ph. D. dissertation, Universidade Federal de Pelotas, Pelotas.

Morandi Filho, W. J., A. D. Grützmacher, M. Botton, and A. Bertin. 2008. Biologia e tabela de vida de fertilidade de Planococcus citri em diferentes estruturas vegetativas de cultivares de videira. Pesqui. Agropecu. Bras. 43: 941-947.

Nachtigal, J. C. 2003. Produção de Mudas de Videira em Regiões Tropicais e Subtropicais. Embrapa Uva e Vinho (Circular Técnica, 46), Bento Gonçalves, RS.

Nelder, J. A., and R.W.M. Wedderburn. 1972. Generalized linear models. J. R Stat. Soc. A 135: 370-384.

Parra, J.R.P. 2001. Técnicas de Criação de Insetos Para Programas de Controle Biológico. FEALQ, Piracicaba, SP.

R Development Core Team. 2012. R: a language and environment for statistical computing. (http://www.Rproject.org/).

Risebrow, A., and A.F.G. Dixon. 1987. Nutritional ecology of phloem feeding insects, pp. 421-448. In F. Slansky, Jr., and J. G. Rodriguez (eds.), Nutritional Ecology of Insects, Mites, Spiders and Related Invertebrates. Wiley, New York, NY.

Santa-Cecília, L.V.C., V.H.P. Bueno, and E. Prado. 2004. Desenvolvimento de Dysmicoccus brevipes (Cockerell) (Hemiptera: Pseudococcidae) em duas cultivares de abacaxi. Ciênc. Agrotec 28: 1015-1020.

Schoonhoven, L. M., J.J.A. van Loon, and M. Dicke. 2005. Insect-plant biology. Oxford University Press, New York, NY.

Silva, A.G.A., C. R. Gonçalves, D. M. Galvão, A.J.L. Gonçalves, J. Gomes, M. do N. Silva, and L. de. Simoni. 1968. Quarto Catálogo dos Insetos que Vivem nas Plantas do Brasil Seus Parasitos e Predadores. Ministério da Agricultura, Rio de Janeiro, RJ.

Walton, V. M., and K. L. Pringle. 2004. Vine mealybug, Planococcus ficus (Signoret) (Hemiptera: Pseudococcidae), a key pest in South African vineyards. Rev. S. Afr. J. Enol. Vit. 25: 54-62.

Received 14 March 2013; accepted 14 July 2013. 